\title{
Turkeys Befriend a Girl: Turkey Husbandry, Ceremonialism, and Tales of Resistance during the Pueblo Revolt Era - Addendum
}

\author{
Lynda D. McNeil
}

DOI: 10.1017/aaq.2021.111. Published online by Cambridge University Press, November 8, 2021.

$\mathrm{S}$ ince this article (McNeil 2022) was published, the Maxwell Museum has conducted further research on the Biscuit ware vessel from Sapawe mentioned on page 27 of the article (Maxwell Museum catalog \#:66.105.52; UNM excavations at Sapawe 1964) and has determined that the pot is not from a human burial context but rather from Plaza D, Room DE 7.

\section{Reference Cited}

McNeil, Lynda D.

2022 Turkeys Befriend a Girl: Turkey Husbandry, Ceremonialism, and Tales of Resistance during the Pueblo Revolt Era. American Antiquity 87:18-41. 